\title{
The diet, growth and survival of Razorbill Alca torda chicks in the southern Barents Sea
}

\author{
Robert T. Barrett
}

Department of Natural Sciences, Tromsø University Museum, PO Box 6050 Langnes, N-9037 Tromsø, Norway; e-mail: rob.barrett@uit.no

\begin{abstract}
Over 32 years (1981-2013), Razorbills Alca torda breeding at Hornøya, NE Norway fed their chicks on capelin Mallotus villosus, sandeels Ammodytes spp. and, sometimes, I-group herring Clupea harengus. It seems that Razorbills are opportunistic and feed their chicks the youngest stages of herring in years when the latter are numerous in the southern Barents Sea. Increasing sea temperatures and resulting shifts in fish distribution may result in fewer capelin and more herring and sandeels in the chick diet.
\end{abstract}

Keywords: chick diet, capelin, sandeel, herring

\section{INTRODUCTION}

The Razorbill Alca torda is a large auk that breeds in boreal and sub-Arctic waters of the North Atlantic. The global population is estimated to be around 600000 pairs with $>500000$ pairs in the NE Atlantic and 40000-50000 pairs in Norway (Mitchell et al. 2004, Fauchald et al. 2015). Despite its size and abundance, relatively little has been published about the Razorbill compared to other auks such as the Guillemots Uria spp. and the Atlantic Puffin Fratercula arctica (Gaston \& Jones 1998). This is probably due to its habit to breed in discreet pairs, half-hidden on often nearinaccessible nest sites. Symptomatic of this was the only partial inclusion of the species in long-term (from 1980 and ongoing) studies of seabirds at Hornøya, NE Norway that concentrated on more common and more accessible species (e.g. Furness \& Barrett 1985, Barrett 2001). Among the parameters studied was chick diet, and capelin Mallotus villosus, sandeels Ammodytes sp., I-group (approx. one year old) herring Clupea harengus which are all lipid- and energy-rich fish, as well as less nutritious gadid fry were found to be important constituents of the diet of most species occupying the

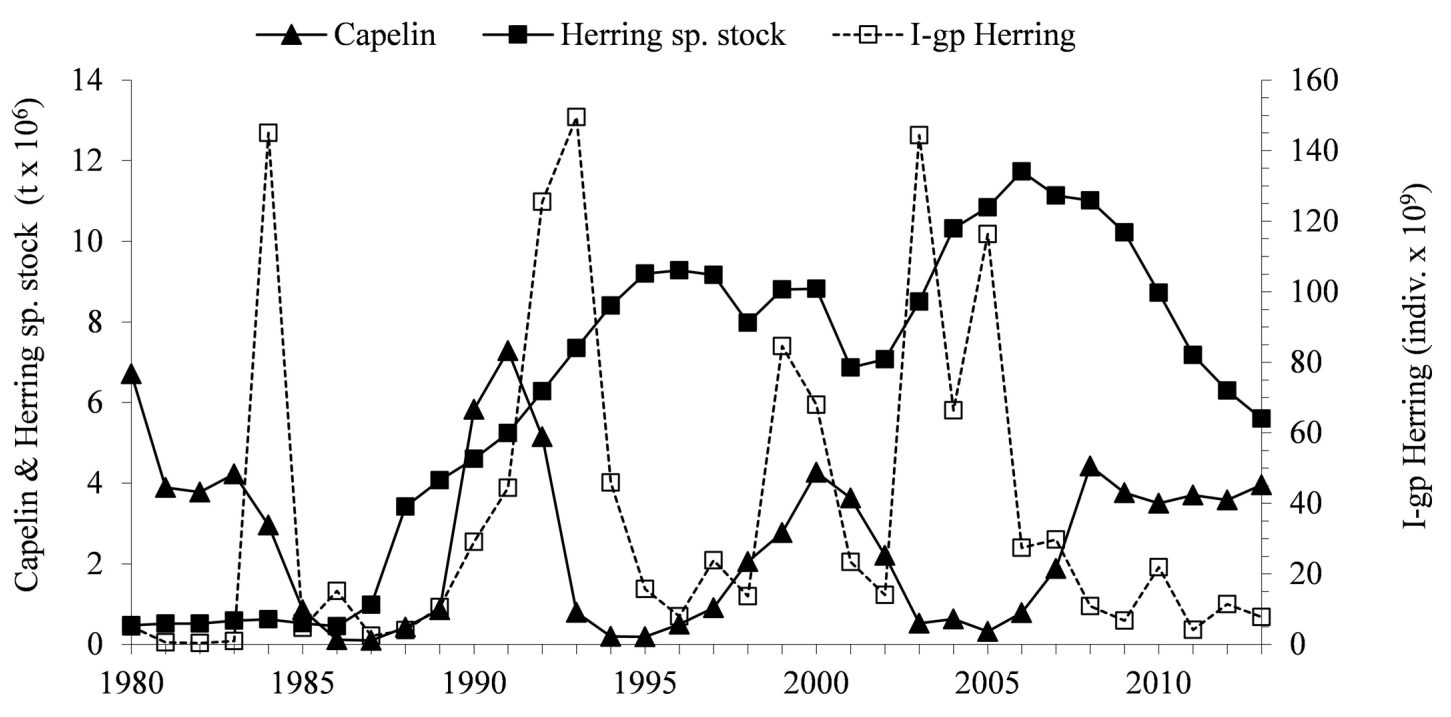

Figure 1. Estimates of the stocks of capelin and Norwegian spring-spawning herring in Norwegian waters. The spawning stocks are given in millions of tonnes whereas that of I-group herring is in numbers of individuals (x 10 ${ }^{9}$ ). Source ICES (2014 - Tables 7.7.3.3.1 \& 7.7.3.3.3) and ICES (2015 - Table 9.5). 


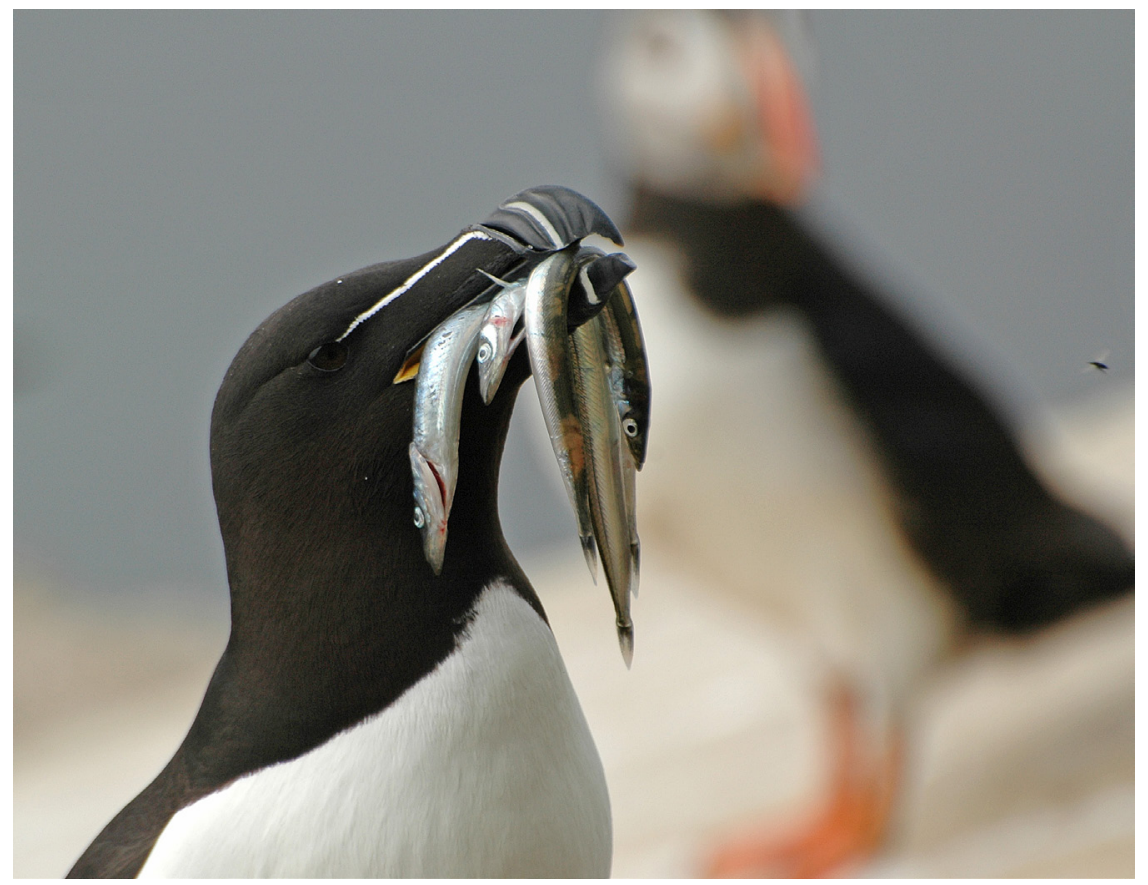

Figure 2. An adult Razorbill carrying three large sand eels for its chick at Hornøya, NE Norway, July 2008. Photo: Rob Barrett.

colony. Razorbills were no exception and in 1983, 1989 and the 1990s, when the Norwegian spring-spawning herring stocks were very low and recovering from a huge collapse in the 1960s (Dragesund et al. (1997), Figure 1), they fed their chicks mainly on sandeels, with capelin as a second choice (Barrett 1984, Furness \& Barrett 1985, Barrett \& Furness 1990). A later study (Barrett 2003), carried out in the early stages of the herring stock recovery (1990-2002) suggested, however, that herring, when available, may actually be more important for southern Barents Sea Razorbills than previously suggested. That I-group herring that has an important nursery area in the southern Barents Sea could be an important prey for Razorbills in the region was earlier noted by Belopol'skii (1957) in his study at a colony on the Murmansk coast between 1935 and 1951, a period before the collapse of the herring stock. In the absence of this potentially important prey, chick growth rates, fledging periods and breeding success measured in 1981 and 1982 were nevertheless high (Barrett 1984) implying that capelin and sandeels were readily available near the colony and suitable as alternative prey. This study addresses diet choice, chick growth rates and pre-fledging survival of Razorbill chicks at Hornøya and the importance of herring in chick diet over a 32-year period, with and without herring, when herring stocks were recovering. It builds partly on data published in Barrett (2003).

\section{METHODS}

Adult Razorbills deliver to their chicks fish, and rarely invertebrates, held crosswise in their bills (Figure 2).
Food items brought into the colony at Hornøya $\left(70^{\circ}\right.$ $23^{\prime} \mathrm{N}, 31^{\circ} 09^{\prime} \mathrm{E}$ ) were recorded in 1983, 1990 and 1993-2013 using 10 x 40 binoculars. Food items were identified to species, counted and their size estimated as multiples of the straight bill length (ca. $30 \mathrm{~mm}$ ). The mass of individual fish was estimated from length/mass relationships from samples collected in the colony.

Growth rates of chicks (mass gain $\mathrm{g} \mathrm{d}^{-1}$ or wing growth $\mathrm{mm} \mathrm{d}^{-1}$ ) were estimated by dividing the change in body mass or wing length by the time interval between measurements made every $5-15 \mathrm{~d}$ in 30-40 control nests. Using wing-length as a proxy for age, these estimates were restricted to measurements made in the linear phase of mass increase from hatching to an age when wing length $=65 \mathrm{~mm}$ ( $\equiv$ ca. $15 \mathrm{~d}$, a few days before the chicks can be expected to leave the colony, Barrett 1984).

Chick survival was determined as the number of chicks hatched that survived until the last inspection day of the field season by which time $75 \%$ of the surviving chicks had reached ages of $15 \mathrm{~d}$ or more. Survival data from 2011 and $2012(<30 \%)$ were excluded from statistical analyses due to observed excessive predation by mink Neovison vison in the region of the control burrows masking any effect of food supply.

Fish stock data were taken from annual reports of the Working Groups of the International Council for the Exploration of the Seas (ICES) (ICES 2014 - Tables 7.7.3.3.1 and 7.7.3.3.3 for I-group herring and total spawning stock respectively, and ICES 2015 - Table 9.5 for capelin). There are, however, no estimates of the size of the local sandeel stocks (Bergstad et al. 2013). Chick diet composition, growth and survival rates were related to the abundance/biomass of capelin 


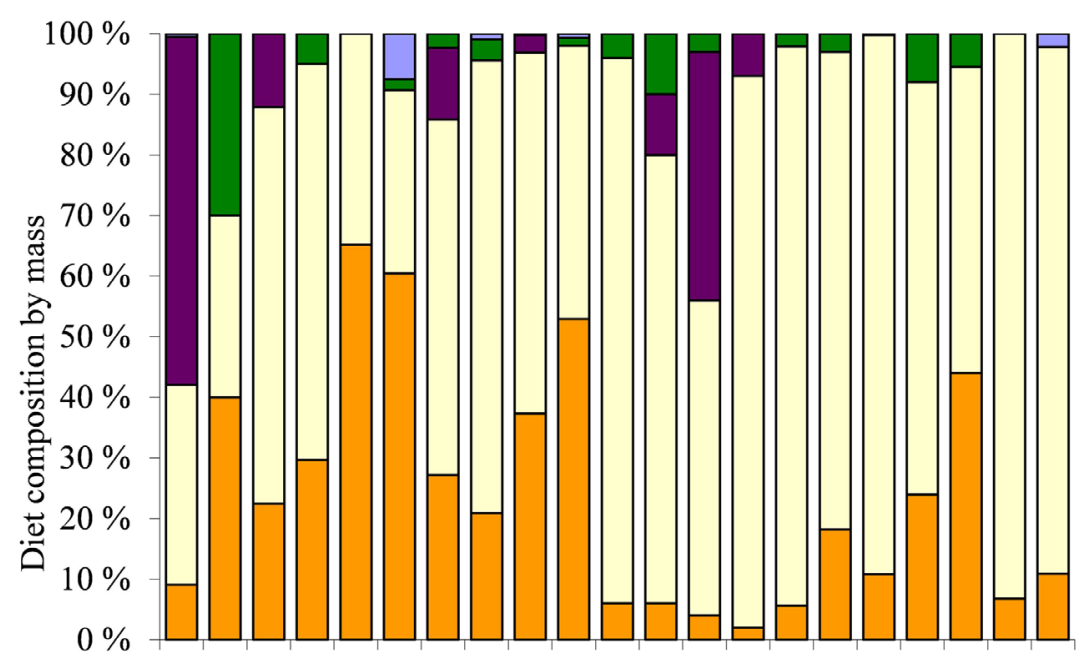

Figure 3. Composition of Razorbill chick diet (by mass and by number) at Hornøya, NE Norway, 1993-2013. Numbers between figures $=$ numbers of food loads recorded.

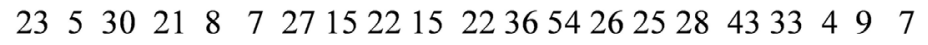

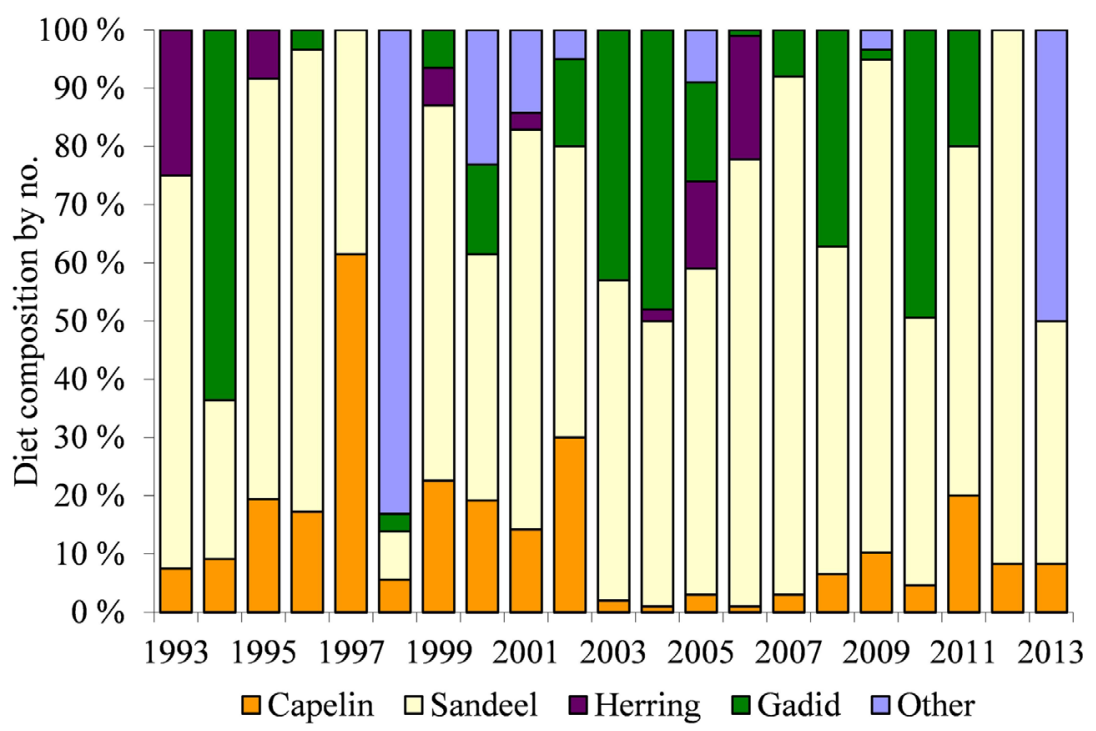

and I-group herring using simple regression analyses. An underlying assumption was that availability of capelin and I-group herring to Razorbills reflected the abundances/biomass of the fishes as estimated for their total areas of distribution.

\section{RESULTS}

Chick diet varied considerably from year to year both when analysed as $\%$ of the total food mass and as $\%$ of the total number of food items (Figure 3) sampled each season. Capelin and sandeels dominated the overall picture and only in 1993, 1995, 1999 and 2005 did herring constitute $>10 \%$ of the diet by mass with $58 \%$ in 1993 and $41 \%$ in 2005 . When numbers of fish are considered, gadids became more evident in several years, as did seemingly "other" fish in 1998 and 2013. Sample sizes in 1998 and 2013 were, however, small ( $n=7$ both years) and single samples consisting of numerous very small, unidentified larvae thus had large influences. By mass, these larvae made up very little of the total composition. Gadid fry were quite numerous in several seasons, but only in 1994 (but again when the sample size was small) did they constitute $>10 \%$ by mass. While the amount of herring by number in the diet was not related to the numbers of herring of the same age group (1-year olds), there was a weak relationship with the amount of herring by mass (Figure 4). There was otherwise no relationship between amounts of capelin or sandeels by mass or by number in the diet with ICES stock estimates of either I-group herring or capelin.

Annual mean growth rates of chicks also varied considerably (mass: $\mathrm{F}_{14,338}=2.6, \mathrm{p}=0.001$; wing: $\mathrm{F}_{23,684}$ $=2.6, \mathrm{p}<0.001$ when excluding samples fewer than 10 measurements in any one year) with mean mass increments of 8.8-12.5 $\mathrm{g} \mathrm{d}^{-1}$ and wing-length increments of 3.1-3.8 $\mathrm{mm} \mathrm{d}^{-1}$. There were no tendencies towards time trends in either parameter over the years of the study (Figure 5, Appendix 1) but there were marked dips in mass gain in 2009 and 2011 and in wing growth in 1995 and 2011. Annual mean growth rates were not 


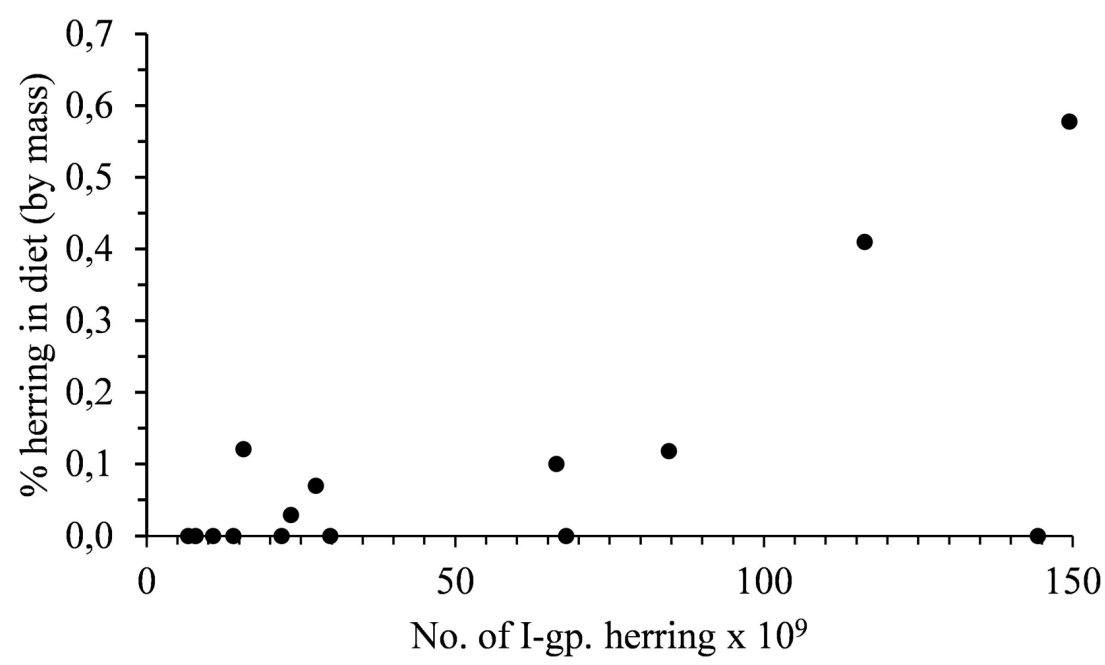

Figure 4. Relationship between \% herring (by mass) in Razorbill chick diet at Hornøya, NE Norway and numbers of I-gp herring in Norwegian waters. Herring data from ICES WGWIDE Report 2014. (\% herring arcsine transformed, $y=-0.029+0.002 x, r^{2}=$ $0.45, \mathrm{p}=0.006)$.

related to either diet composition or fish stocks.

Between 60 and $90 \%$ of the hatched chicks survived the first four weeks post-hatch in 18 of the 21 years with data (Figure 6). In 2007, only 53\% survived and in 2011 and 2012 only $7 \%$ and $16 \%$ survived respectively. In the latter two years, exceptional mink activity was seen in parts of the colony (pers. obs.). There was no evidence of a long-term trend in survival rates when excluding data for 2011 and 2012 with an overall mean of $76.2 \%(\mathrm{SE}=0.02)$. Nor were there any relationships between chick survival rates (again excluding 2011 and 2012) and diet composition, growth rates or stocks of capelin or I-group herring.

\section{DISCUSSION}

Because Razorbills breed widely spread in the colony at Hornøya, numbers of diet observations in this study were small, limiting scope for drawing conclusions. This was exacerbated in the latter years of this study when, despite an increased field effort, sample sizes dropped considerably (Figure 3). This was due to an expansion of Common Guillemot Uria aalge nesting areas in the colony cutting off access to the prime Razorbill sites (pers. obs.). As a result, it became increasingly difficult to observe the Razorbills in detail as they returned to their nest sites.

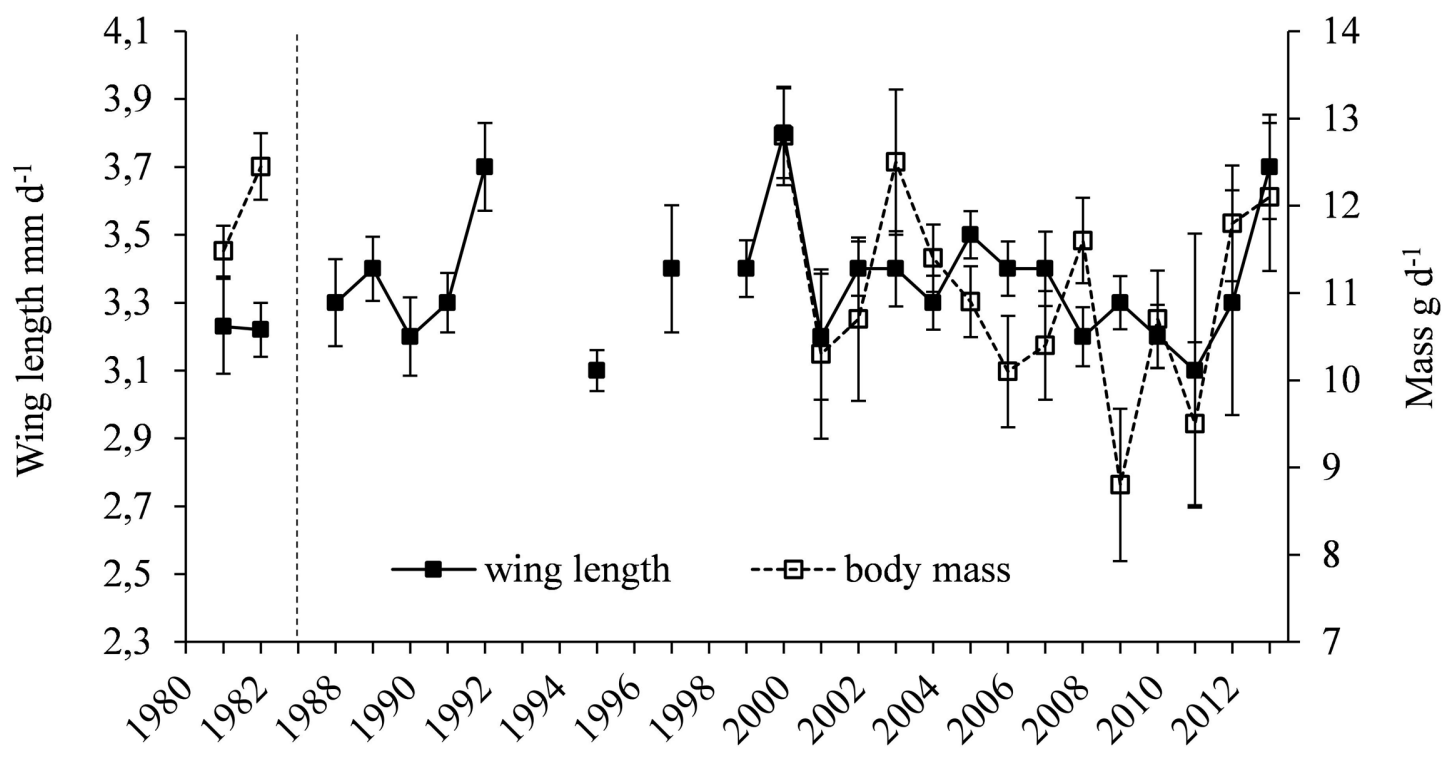

Figure 5. Mean growth rates (body mass $\mathrm{g} \mathrm{d}^{-1}$ and wing length $\mathrm{mm} \mathrm{d}^{-1} \pm 1 \mathrm{SE}$ ) of Razorbill chicks at Hornøya, NE Norway, 19812013. $\mathrm{n}>10$, see Appendix1. Note the break in the $\mathrm{x}$-axis marked by the vertical dotted line. 


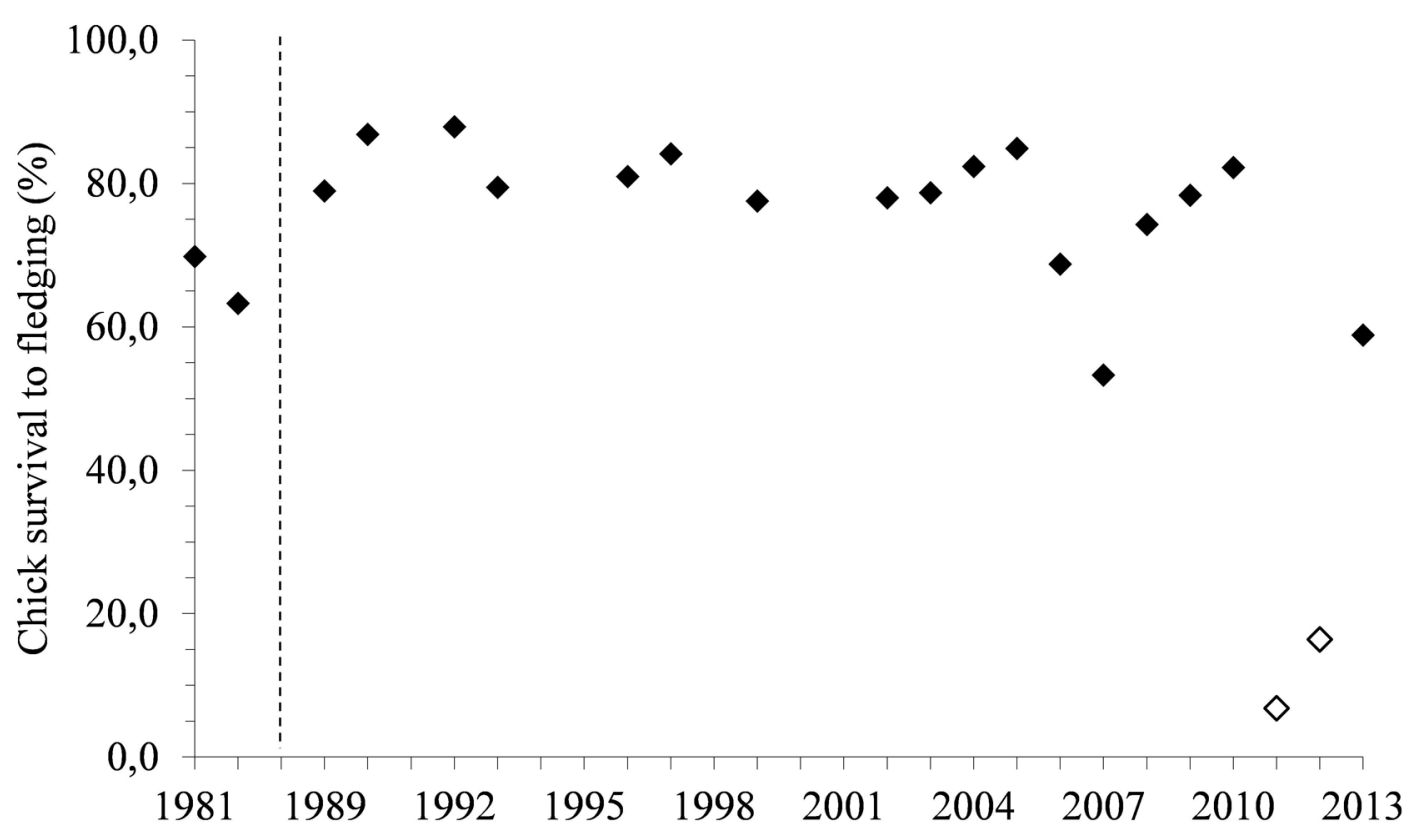

Figure 6. Mean survival rates of Razorbill chicks after hatching to age $15 \mathrm{~d}$ or more at Hornøya, NE Norway, 1981-2013. The exceptionally low rates in 2011 and 2012 (open symbols) were attributed to excessive predation by mink). Note the break in the $\mathrm{x}$-axis marked by the vertical dotted line.

As in the preceding studies that covered 1981-1982, the 1990s, 2001 and 2002 (Barrett 1984, 2003), sandeels and capelin continued to dominate the diet of Razorbill chicks at Hornøya for the next 11 years. The suggestion, however, that I-group herring might be more important than originally considered was only partly supported by the apparent relationship between amounts of herring in the diet and ICES' annual estimates of numbers of I-group herring in the Norwegian seas. This and the abundance of capelin in the diet suggest that adult Razorbills do not preferentially select sandeels to the same degree as found in e.g. the UK (Harris \& Wanless 1986, Wagner 1997 - see also Gaston \& Jones 1998), but that they feed opportunistically taking what is most available. Capelin (and probably also sandeels) are, however, likely easier to catch than herring as the former have a weaker and slower predator avoidance reaction than young herring (Axelsen et al. 2001, Jørgensen et al. 2004, Chivers et al. 2012). As such, Razorbills may target herring only in the years they are readily available rather than spend time and energy searching for and catching them when numbers are low.

Although the mean daily growth rates of the Razorbill chicks varied considerably from year to year, they remained at the maximum of that recorded for the species. Three studies of Canadian populations of birds of similar body size documented chick growth rates of 9-10 $\mathrm{g} \mathrm{d}^{-1}$ whereas the growth rates of chicks of smaller birds in Wales averaged $8.3 \mathrm{~g} \mathrm{~d}^{-1}$ (Hipfner \& Chapdelaine 2002). Only in 2009 and 2011 were the mean daily mass increments at Hornøya below $10 \mathrm{~g} \mathrm{~d}^{-1}$ (Figure 5). Wing growth too was low and the low mass gain these two seasons (and partly also 2005-2007) suggest an allocation of resources into structural growth at the expense of mass gain (fat deposition), a strategy that is normal for long-lived seabirds in times of food shortage (Øyan \& Anker-Nilssen 1996, Morrison et al. 2009, Lyons \& Roby 2011). There was, however, little evidence of food shortage in 2009 when many sandeelrich food loads and a high chick survival were recorded. In 2011, on the other hand, a similar dip in growth rates was recorded among Atlantic Puffin and Common Guillemot chicks at Hornøya (Barrett \& Erikstad 2013, Barrett in press) and there was also a sudden midseason change in foraging behaviour accompanied by a near complete breeding failure among Blacklegged Kittiwakes Rissa tridactyla. The latter was interpreted as a northward shift in capelin (its preferred prey, Barrett 2007) distribution causing a critical food shortage for this surface-feeding species (Ponchon et al. 2014). Similarly in 1995, when Razorbill chick growth was again very low, kittiwake breeding success was the lowest for that decade (53\%) and capelin made up only $24 \%$ of the chick diet (pers. obs.), again suggesting a shortage of this important prey. There are, however, no data concerning the energy and protein content of the Razorbill food items, parameters known to vary considerably within and between seasons and to have considerable effect on chick growth and reproductive output of auks (Pedersen \& Hislop 2001, Wanless et al. 2005). Nor are there data concerning possible annual differences in feeding frequencies so the overall effect of changing fish availability and possible food shortages on the Razorbills is unknown.

Although not conclusive, this study corroborates earlier documentation that capelin and sandeel are the 
main prey of Razorbills at Hornøya (Barrett 2003) and that I-group herring, when available, is included as a supplementary item in the chick diet The longterm increase in sea temperatures as a result of global warming is predicted to cause a distribution shift of fish populations causing a northward shift of capelin out of, and bringing more young herring (and possibly also more sandeels) to the Barents Sea into the foraging range of seabirds at Hornøya (Stenevik \& Sundby 2007). Herring is of high nutritional value and any increase in its availability may be positive for Razorbills (in contrast to Black-legged Kittiwakes [Barrett 2007]) breeding in the region, but the effects of warming on the long-established trophic interactions and links between temperature and biological parameters remain unknown (Johannesen et al. 2012).

Acknowledgements. I thank the Norwegian Coastal Administration for permission to use the lighthouse on Hornøya as a base for fieldwork and Håkon Dahlen, Laila Dalheim and Magne Asheim for help with food observations and collections. I am also grateful to Tone Reiertsen, Bill Montevecchi and Odd Aksel Bergstad for comments on earlier drafts of the manuscript. The study was financed by the Norwegian Research Council, The Norwegian Directorate for Nature Management (now Norwegian Environment Agency), the University of Troms $\varnothing$ and the Norwegian SEAPOP programme (www.seapop.no)

\section{REFERENCES}

Axelsen, B.E., Anker-Nilssen, T., Fossum, P., Kvamme, C. \& Nøttestad, L. 2001. Pretty patterns but simple strategy: predator-prey interactions between juvenile herring and Atlantic Puffins observed with multibeam sonar. Canadian Journal of Zoology 79: 1586-1596.

Barrett, R.T. 1984. Comparative notes on eggs, chick growth and fledging of the Razorbill Alca torda in north Norway. Seabird 7: 55-61.

Barrett, R. T. 2001. Monitoring the Atlantic Puffin Fratercula arctica, Common Guillemot Uria aalge and Blacklegged Kittiwake Rissa tridactyla breeding populations on Hornøya, northeast Norway, 1980-2000. Fauna norvegica 21: 1-10.

Barrett, R.T. 2003. The food of Razorbill Alca torda chicks on Hornøya, North Norway. Ornis Norvegica 26: 48-54.

Barrett, R.T. 2007. Food web interactions in the southwestern Barents Sea: Black-legged Kittiwakes Rissa tridactyla respond negatively to an increase in herring Clupea harengus. Marine Ecology Progress Series 349: 269 276.

Barrett, R.T. In press. Atlantic Puffin Fratercula arctica chick growth in relation to food load composition. Seabird.

Barrett, R.T. \& Erikstad, K.E. 2013. Environmental variability and fledging body mass of Common Guillemot Uria aalge chicks. Marine Biology 160: 1239-1248.

Barrett, R.T. \& Furness, R.W. 1990. The prey and diving depths of seabirds on Hornøya, North Norway after a decrease in the Barents Sea capelin stocks. Ornis Scandinavica 21: 179-186.

Belopol'skii, L.O. 1957. Ecology of sea colony birds of the Barents Sea. Israel Program for Scientific Translations, Jerusalem.

Bergstad, O.A., Johannessen, T., Anker-Nilssen, T. \& Barrett, R.T. 2013. Fagrapport for tobis (Ammodytidae) på norskekysten - kunnskapsoversikt med forslag til tiltak. Miljødirektoratet Rapport M5-2013, Trondheim.

Chivers, L.S., Lundy, M.G. \& Reid, N. 2012. Stable breeding despite variable feeding in two sympatric auk (Alcidae) species. Bird Study 59: 67-73.

Dragesund, O., Johannessen, A. \& Ulltang, Ø. 1997. Variation in migration and abundance of Norwegian spring spawning herring (Clupea harengus L.). Sarsia 82: 97-105.

Fauchald, P., Anker-Nilssen, T., Barrett, R.T., Bustnes, J.O., Bårdsen, B.-J., Christensen-Dalsgaard, S., Descamps, S., Engen, S., Erikstad, K.E., Hanssen, S.A., Lorentsen, S.-H., Moe, B., Reiertsen, T.K., Strøm, H. \& Systad, G.H. 2015. The status and trends of seabirds breeding in Norway and Svalbard. NINA Report 1151, NINA, Trondheim.

Furness, R.E. \& Barrett, R.T. 1985. The food requirements and ecological relationships of a seabird community in North Norway. Ornis Scandinavica 16: 305-313.

Gaston, A.J. \& Jones, I.L. 1998. Bird families of the world. The Auks. Oxford University Press, Oxford.

Harris, M.P. \& Wanless, S. 1986. The food of young Razorbills at the Isle of May and a comparison with that of young guillemots and puffins. Ornis Scandinavica 17: 41-46.

Hipfner, J.M. \& Chapdelaine, G. 2002. Razorbill Alca torda. In Poole, A. \& Gill, F. (eds.) The Birds of North America, No. 635. The Birds of North America Inc., Philadelphia.

ICES. 2014. Report of the Report of the Working Group on Widely Distributed Stocks (WGWIDE). Int. Council for the Exploration of the Sea, Copenhagen.

ICES. 2015. Report of the Arctic Fisheries Working Group (AFWG). ICES CM 2015/ACOM:05, Int. Council for the Exploration of the Sea, Copenhagen.

Johannesen, E., Ingvaldsen, R.B., Bogstad, B., Dalpadado, P., Eriksen, E., Gjøsæther, H., Knutsen, T., Skern-Mauritzen, M. \& Stiansen, J.E. 2012. Changes in Barents Sea ecosystem state 1970-2009. Climate fluctuations human impact and trophic interactions. ICES Journal of Marine Science 69: 880-889.

Jørgensen, R., Handegard, N.O., Gjøsæter, H. \& Slotte, A. 2004. Possible vessel avoidance behaviour of capelin in a feeding area and on a spawning ground. Fisheries Research 69: 251-261.

Lyons, D. E. \& Roby, D. D. 2011. Validating growth and development of a seabird as an indicator of food availability: captive-reared Caspian Tern chicks fed ad libitum and restricted diets. Journal of Field Ornithology 82: 88-100.

Mitchell, P.I., Newton, S.F., Ratcliffe, N. \& Dunn, T.E. 2004. 
Seabird populations of Britain and Ireland. T. \& A.D. Poyser, London.

Morrison, K.W., Hipfner, J.-M., Gjerdrum, C. \& Green, D.J. 2009. Wing length and mass at fledging predict local juvenile survival and age at first return in Tufted Puffins. Condor 111: 433-441.

Pedersen, J \& Hislop, J.R.G. 2001. Seasonal variations in the energy density of fishes in the North Sea. Journal of Fish Biology 59: 380-389.

Ponchon, A., Grémillet, D., Christensen-Dalsgaard, S., Erikstad, K.E., Barrett, R.T., Reiertsen, T.K., McCoy, K.D., Tveraa, T. \& Boulinier, T. 2014. When things go wrong: intra-season dynamics of breeding failure in a seabird. Ecosphere 5(1): 4. http://dx.doi.org/10.1890/ ES13-00233.1
Stenevik, E.K. \& Sundby, S. 2007. Impacts of climate change on commercial fish stocks in Norwegian waters. Marine Policy 31: 19-31.

Wagner, R.H. 1997. Differences in prey species delivered to nestling by male and female Razorbills Alca torda. Seabird 19: 58-59.

Wanless, S., Harris, M.P., Redman, P. \& Speakman, J.R. 2005. Low energy values of fish as probable cause of a major breeding failure in the North Sea. Marine Ecology Progress Series 294: 1-8.

Øyan, H. S. \& Anker-Nilssen, T. 1996. Allocation of growth in food-stressed Atlantic Puffin chicks. Auk 113: 830841.

Received 9 October 2015. Accepted 2 November 2015

Appendix1. Annual means of daily growth rates of razorbill chicks at Hornøya, NE Norway, 1980-2013. Mass measurements were made in the linear phase of growth and ceased when wing length $=65 \mathrm{~mm}$. SE $=$ standard error, $\mathrm{n}=$ sample size, $\mathrm{nd}=$ no data.

\begin{tabular}{|c|c|c|c|c|c|c|}
\hline \multirow[t]{2}{*}{ Year } & \multicolumn{3}{|c|}{ Body mass $\mathrm{g} \mathrm{d}^{-1}$} & \multicolumn{3}{|c|}{ Wing length $\mathrm{mm} \mathrm{d}^{-1}$} \\
\hline & Mean & SE & $\mathrm{n}$ & Mean & SE & $\mathrm{n}$ \\
\hline 1981 & 11.5 & 0.3 & 30 & 3.3 & 0.1 & 30 \\
\hline 1982 & 12.5 & 0.4 & 30 & 3.2 & 0.1 & 30 \\
\hline 1988 & 10.8 & 1.3 & 6 & 3.3 & 0.1 & 30 \\
\hline 1989 & 10.0 & 1.5 & 6 & 3.4 & 0.1 & 28 \\
\hline 1990 & nd & nd & nd & 3.2 & 0.1 & 12 \\
\hline 1991 & nd & nd & nd & 3.3 & 0.1 & 21 \\
\hline 1992 & nd & nd & nd & 3.7 & 0.1 & 15 \\
\hline 1995 & nd & nd & nd & 3.1 & 0.1 & 11 \\
\hline 1996 & nd & nd & nd & 3.4 & 0.1 & 9 \\
\hline 1997 & 12.7 & 0.3 & 7 & 3.4 & 0.2 & 23 \\
\hline 1998 & nd & nd & nd & 4.4 & 1.0 & 8 \\
\hline 1999 & nd & nd & nd & 3.4 & 0.1 & 23 \\
\hline 2000 & 12.8 & 0.6 & 8 & 3.8 & 0.1 & 28 \\
\hline 2001 & 10.3 & 1.0 & 13 & 3.2 & 0.2 & 29 \\
\hline 2002 & 10.7 & 0.9 & 14 & 3.4 & 0.1 & 39 \\
\hline 2003 & 12.5 & 0.8 & 23 & 3.4 & 0.1 & 40 \\
\hline 2004 & 11.4 & 0.4 & 27 & 3.3 & 0.1 & 40 \\
\hline 2005 & 10.9 & 0.4 & 32 & 3.5 & 0.1 & 52 \\
\hline 2006 & 10.1 & 0.6 & 25 & 3.4 & 0.1 & 39 \\
\hline 2007 & 10.4 & 0.6 & 28 & 3.4 & 0.1 & 30 \\
\hline 2008 & 11.5 & 0.5 & 24 & 3.2 & 0.1 & 33 \\
\hline 2009 & 8.8 & 0.9 & 20 & 3.3 & 0.1 & 41 \\
\hline 2010 & 10.7 & 0.6 & 35 & 3.2 & 0.1 & 41 \\
\hline 2011 & 9.5 & 0.9 & 11 & 3.1 & 0.4 & 12 \\
\hline 2012 & 11.8 & 0.7 & 11 & 3.3 & 0.3 & 11 \\
\hline 2013 & 12.1 & 0.9 & 27 & 3.7 & 0.2 & 27 \\
\hline
\end{tabular}

